\title{
The Brazilian Amazon in Times of COVID-19: from crisis to transformation?
}

\author{
Fabio de Castro \\ Gabriela Russo Lopes \\ Eduardo Sonnewend Brondizio
}

${ }^{1}$ Centre for Latin American Research and Documentation (CEDLA), University of Amsterdam.

The Netherlands - Amsterdam

"Centre for Latin American Research and Documentation (CEDLA), University of Amsterdam, Amsterdam

The Netherlands - Amsterdam

III Department of Anthropology and Center for the Analysis of Social- Ecological Landscapes (CASEL), Indiana University Bloomington, USA. Environment and Society Program (NEPAM), University of Campinas (UNICAMP) Campinas/SP - Brasil

\begin{abstract}
The COVID-19 crisis is not a new issue. Conditions leading to it have been taking shape for decades. This pandemic is rather a symptom of much deeper challenges resulting from contemporary production and consumption structures, social inequalities, nature deterioration, and global connectivity. To think about the post-pandemic world is to envision solutions that tackle the root causes of the problem. Local communities and indigenous groups in the Brazilian Amazon are a source of much-needed social innovations that rely on alternative views of Nature and social relations. This essay aims to turn the attention to these practices as starting point to rethink our present and reshape our future. New pathways are needed in order to overcome the region's 'old normal' marked by destructive resource expropriation and social inequalities, and move to a 'new normal' that rely on transformations to a more sustainable and equity-based society.
\end{abstract}

Keywords: COVID-19, Amazon, Rural populations, Indigenous groups, Sustainable transformation

São Paulo. Vol. 23, 2020

Debating ideas

The COVID-19 epoch: Interdisciplinary research towards a new just and sustainable ethics

DOI: http://dx.doi.org/10.1590/1809-4422asoc20200123vu2020L3ID 


\section{Introduction}

When the COVID-19 outbreak in China was first reported in late December 2019, no one could imagine its global impact (WHO, 2020a). The virus spread rapidly worldwide, triggering disruptions in social, economic and political structures, and exposing latent geopolitical tensions. Discussions and proposals around herd immunization revealed how human lives can be reduced to currency by capitalist logics (HARVEY, 2020). Data manipulation, fake news and infodemics (WHO, 2020b) showed how science can be overridden by vested interests (BRENNEN et al., 2020). Social distancing measures exposed the dilemma between individual freedom, family needs and collective solidarity faced by citizens (NAY, 2020). Ultimately, this pandemic reminded us that our relation with Nature and with each other has crossed the line of sustainability, safety, and justice (IPBES, 2019; DIAZ et al., 2020).

This pandemic is not a new process (VANWAMBEKE et al., 2019). Like almost all recent emerging infectious diseases, the evidences to date indicate that the corona virus is zoonotic in origin, transmitted from animal to human, particularly evident in frontier areas where wildlife is impacted by depleted natural habitats. It exposes the interconnectivity between humans and its surrounding environment (DI MARCO et al., 2020). Human-led interventions on nature such as deforestation, environmental degradation, food and water contamination, animal husbandry practices and wildlife commercialization, increase the risks of interspecies cross-contamination.

The current global crisis, however, goes beyond factors driving the emergence of this pandemic. It reminds us that we are interdependent societies and challenged to respond collectively and timely to global threats. The social and economic outcomes of the COVID-19 crisis have been one of the most damaging in this century. According to WHO (2020a), it has hit 216 countries, infected over 5.2 million people, and caused over 340 thousand fatalities to date, and continues to grow. These figures are underestimated as many cases go unreported. This invisible enemy proves that military power and high technologies are not enough to ensure a country's safety; rather science and proper leadership, provision of public goods, collective action, international cooperation, and widespread solidarity are the most effective weapons for this war. The message is clear: a major societal transformation towards socially just sustainability is needed, one that addresses our current relation with Nature and with ourselves.

In this essay, we discuss the challenges and opportunities brought about by the COVID-19 crisis and ensuing responses. We focus on the Brazilian Amazon, a megabiologically and culturally diverse region where environmental depletion is fast-paced and social inequalities are high. The region faces a three-fold challenge in this crisis: preventing the virus to spread among densely populated urban areas marked by socioeconomic insecurity and deplorable sanitary conditions; rural populations living in 'health service deserts' with limited communication and mobility to already collapsing urban health services; and indigenous populations with equally limited support and immunologically vulnerable (PARRY et al., 2018). The latter two have been particularly invisible in this debate. After a brief presentation of the national political context, we discuss the potential 
roles that Amazonian marginalized rural and Indigenous populations play, highlighting a range of innovative activities, mostly invisible, which can help build pathways to a 'new normal' that reconcile production, conservation and social justice. We conclude by underlining the transformative opportunities for the region in a post-pandemic world.

\section{Political Context of COVID-19 in Brazil}

The first case of COVID-19 in Brazil was announced in late January 2020 and $^{1}$, ever since, the number of infections soared, reaching one of the highest rates in the world (BHATIA et al., 2020). Brazil is now becoming an epicenter of the COVID-19 pandemic (MELLAN et al., 2020). In 23 May the country moved to the second position in number of infections worldwide (WHO, 2020a), and the overall number of deaths exceeding 22 thousand.

This 'tragedy foretold' results from a combination of complete disdain and mockery from the national government with a highly vulnerable context of the urban and rural poor. Bolsonaro, who referred to the COVID-19 a 'minor flu' ${ }^{2}$ and reacted to the rising death toll with a 'so what? people die', ${ }^{3}$, not only rejected advices from renowned scientists but himself became the main hurdle to fight this crisis (AJZENMAN et al., 2020). The president fired two Health Ministers in less than a month for following the WHO guidelines, clashed with state governors who implemented state-level lockdowns, incited his supporters to public gatherings and protests in front of hospitals, and vilify national institutions such as the Congress and the Supreme Court for positioning against his herd immunization strategy.

Although COVID-19 emerged among the middle-class population who travelled to Europe during the summer vacation, it spread quickly among Brazil's densely populated poor neighborhoods. Residents in these areas cannot afford to follow lockdowns, as they depend on informal jobs for their livelihoods while the financial support from the government remain insufficient and ineffective. They rely on long commuting in packed public transportation and live in small houses with poor, if any, sanitation. The higher death rates in poor neighborhoods in São Paulo attest to their increased vulnerability due to socioeconomic insecurity. Furthermore, recent data reveal a higher death rate among Afro-Brazilian corona patients ${ }^{4}$.

In sum, the COVID-19 has deepened the political crisis and exposed the deep socioeconomic divides in the country. In the next session we discuss how this multiple crisis materializes in the Amazon.

1 - https://saude.estadao.com.br/noticias/geral,primeiro-caso-da-covid-19-no-brasil-e-do-fim-de-janeiro-diz-ministerio-da-saude, 70003258394

2 - https://www.bloomberg.com/news/articles/2020-03-30/-little-flu-can-t-hurt-him-why-bolsonaro-still-shuns-lockdowns

3- https:/www.theguardian.com/world/2020/apr/29/so-what-bolsonaro-shrugs-off-brazil-rising-coronavirus-death-toll

4- https://apublica.org/2020/05/em-duas-semanas-numero-de-negros-mortos-por-coronavirus-e-cinco-vezes-maior-no-br asil/?fbclid=IwAROInF5gpwssVq2h93W3lu6Fa5ltqO_EEiiQeYu1W89HZOS4rza1yvPFprM 


\section{The COVID-19 in the Amazonian Context}

The Amazon region has been one major target of the current national government. Dismantling of environmental regulation and social policies, removal of staff from environmental and indigenous agencies, racist discourse and direct threats against ethnic groups, denial of climate change, and empowerment of actors associated with illegal activities, such as gold-mining, land-grabbing, and deforestation practices have fueled conflict and violence in the region (FERRANTE; FEARNSIDE, 2019). The COVID-19, therefore, adds to a list of increasing threats faced by rural and indigenous populations in the last years.

The Brazilian Amazon accounts for 17\% of corona infections and deaths in the country, mostly in the states of Amazonas and Pará, respectively ranked fourth and sixth in the national statistics. While much attention has been given to the critical situation within the state capitals - such as the early collapse of the health system in Manaus - $^{-}$ the tragedy faced by other states and social groups has been less visible in the national and international media. Amapá and Roraima, for example, are among the states with the highest number of infections per capita in the country (BRASIL, 2020). In addition, infections are progressively advancing to more isolated areas where access to health services is limited and reporting capacity is severely impaired. Intense mobility between rural and surrounding urban centers (ELOY et al., 2014) makes it challenging to monitor transportation (mostly boats). Although public transportation has been put to a halt, local collaborators informed us that private irregular passenger boats remain active.

Indigenous population are particularly in extreme vulnerability as they are more susceptible to virus infections. Their realities vary from large to extremely small groups, some with intense interaction with urban areas, others in relative isolation. Death rate among this group is twice higher than the national average of $6.4 \%$. As of 23 May, 1,140 indigenous from 61 ethnic groups were infected and 131 have died, mostly in the Amazon (APIB, 2020). These figures contrast with official reports which do not account for the approximately $35 \%$ of the Indigenous population that live in urban areas. Cases in Indigenous Territories, however, are particularly worrisome because of a combination of low immunity and their social life based on collective practices. As the history of indigenous genocide associated with infectious diseases reminds us, eventual cases of COVID-19 infection in indigenous territories could mean the extinction of a whole community.

Vulnerability to COVID-19 is further enhanced by the rise in structural state violence through anti-indigenous and pro-land grabbing policies. The Normative Instruction 09, issued in April 2020, and the Provisional Measure 910 currently in discussion in the National Congress open new opportunities for legalizing existing and encouraging new land grabbing tactics, empowering particular private actors to overtake Indigenous Territories and public land more broadly. Compounded by the neglect of the National Indigenous Agency (FUNAI) to confront intensifying threats from illegal activities in indigenous

5 - https://brasil.elpais.com/brasil/2020-05-08/a-beira-do-colapso-manaus-duplica-numero-de-mortes-com-escalada-de-coronavirus.html 
territories and their efforts to promote missionary interactions with 'uncontacted groups', the short- and long-term impact of the virus can indeed become devastating.

Epidemic outbreak, racism and land invasion rekindle the collective memory of colonization and genocide among the indigenous populations. As survivors of a tragic history, this group has particular experience in resistance against the double threat of state and civil violence and pandemic (FAUSTO, 2020). Over recent decades, indigenous groups and a wide array of rural communities in the Amazon have proactively developed local and regional initiatives to address the lack of social services and economic opportunities while respecting human-nature relationships and cultural differences. In the context of the COVID-19 crisis, these groups have recently mobilized around a range of solidarity initiatives in order to provide health support, food, information and material to marginalized groups ${ }^{6} 7$. Their long process of struggles for gaining citizenship, building knowledge, and developing social innovations can give inspirations for possible alternative ways out of the main structural problems behind the COVID-19 pandemic, described in the next section.

\section{The Power of (Invisible) Local Initiatives}

The Amazon has been stage of numerous external interventions, some of them aiming at improvements of Indigenous and rural livelihoods and nature conservation. Over time, these interventions have changed in nature and scope (TOLEDO et al., 2017), from state-based developmentalist projects in the 1970 s to socioenvironmental and community-based initiatives during the 1990s and 2000s to market-based frontier expansion since 2010s. External motivations and design, technocratic-based management, highly subsidized funding, and limited attention to local realities are some of the factors leading to the frequent failure of initiatives (LE TOURNEAU; DROULERS, 2010) or in some cases, deepening conflicts, inequalities, and unsustainable practices.

The accumulated experience from these external interventions also provides the foundation for a new era of local initiatives emerging from genuine participation and management, that reflect rural communities' goals and visions of quality of life. In this sense, the Amazon has been not only a living lab for conflicts but also for innovations. These include transformation of production systems, forms of cooperation, gender empowerment, value-aggregation arrangements, application of local biodiversity knowledge, and alternative forms of relationship with Nature. Although much attention is paid on the conflicts and challenges, we believe that innovative experiences offer inspiration for new pathways to overcome the region's 'old normal' of resource expropriation and social inequalities.

Local initiatives are instrumental in identifying structural bottlenecks that constrain local opportunities perpetuate inequities, and impact local environments. In their own

\footnotetext{
6 - https://www.uol.com.br/vivabem/noticias/redacao/2020/05/02/covid-19-e-indigenas-os-desafios-no-combate-ao-novo-coronavirus.htm

7 - https://www.brasildefato.com.br/2020/05/11/para-combater-a-pandemia-da-fome-mst-ja-doou-mais-de-600-toneladas-de-alimentos
} 
ways, initiatives can also be mutually-reinforcing in addressing multiple social, economic, and environmental goals. For the past year, the AGENTS project ${ }^{8}$ has been documenting and analyzing local initiatives in rural and peri-urban areas aimed at addressing jointly local social needs (e.g., economic improvement), structural problems (e.g., gender inequality, lack of market access, technical assistance), and environmental sustainability (e.g., agroecological transition). Through participatory workshops, field visits, and secondary data sources, our project has identified so far over 200 local initiatives in the state of Pará alone. Two patterns have become clear from this dataset - their invisibility in face of the dominant regional development narrative which favors agribusiness development; and their power to change local conditions, including individual sense of dignity and agency, and collective sense of belonging and autonomy through local innovations, experimentation, and mutual inspiration.

Although just the 'tip of the iceberg', these initiatives address three key aspects: production, market, and/or governance arrangements for sustainable production. From seed funds to women's agro-ecological organization, from community-based agroforestry associations to forest products cooperatives, from farmer-to-farmer knowledge exchange to solidarity networks, they can all provide lessons to the current predicament of investing stimulus and recovery funds in post-pandemic efforts in ways that are just, meaningful and sustainable over the long-run. Below we elaborate on five key lessons emerging from this research.

First, a new investment model (e.g., state, funds, research grants) that addresses common structural problems that continue to plague the region. While highly diverse, local indigenous and rural communities share many common problems, such as social marginalization and lack of political voice, violation of rights (including property rights), limited infrastructure and credit lines, and impaired access to the rule of law and to social services. These shortcomings should be at the basis of public policy and private investment aiming at improving the reality on the ground.

Second, identify local needs locally. Initiatives based on local knowledge and resources must replace the model of externally promoted intervention, often based on panacea solutions across diverse local realities. While common problems should be addressed at the regional level, investments and policies aimed at improving local conditions and resilience to shocks, in a socially just and environmentally sustainable way, demand local participation, leadership and ownership.

Third, support the vast amounts of initiatives already in place in the region. They are built upon local goals, capacity and knowledge and offer opportunities to leverage on existing efforts. There is ample evidence on the power of local governance arrangements, ecological knowledge and resource management systems to reconcile economic contributions and environmental sustainability. Supporting such initiatives not only helps to consolidate previous investments but also helps them to advance faster and be more impactful. 
Fourth, promote synergies across multiple goals through strengthening of local economies. Local initiatives are usually conceived to achieve multiple goals, grounded on the interconnection of economic, food, health, climate, and personal security issues. At the same time, they equate sustainability with local values of a good life, gender equity, and intergenerational rights. Thus a range of practices can leverage one another.

Fifth, nurture a new vision of the future that comes from and that is for the Amazon. The COVID-19 crisis has exposed the region's position as among the poorest and politically disregarded in the world. Since colonial times, the Amazon's most important sources of wealth have been regarded as a stock of commodities, carbon or biodiversity, and visions of sustainable development have usually been a product of centralized government ideology or elite groups advocating for specific interests. Confronting the post-pandemic reality of the region demands attention to structural problems emerging from this vision and empowering the people of the region as agents of change.

\section{Pathways to a New Normal}

The Amazon encapsulates the global transformation in human-nature relationships during the past century. Expansion of large-scale land-use and extractive systems has driven deforestation, biodiversity loss, water contamination and carbon emission, further leading to land dispossession, violence and rural-urban migration. Such dynamics are driven by broader trends in a globalized economy and new patterns of consumption that raise demands for food, feed, energy and materials from ever more distant regions. During this period, the global economy has increased by four-fold and trade by ten-fold, significantly altering $75 \%$ of the land, $66 \%$ of the oceans, and $85 \%$ of wetlands, more than a million species are threatened with extinction (IPBES, 2019). This process has gone hand in hand with increasing inequality, as the world's richest $1 \%$ holds more than twice as much wealth as nearly 7 billion people (OXFAM, 2020).

The fact that the 'enemy' is the simplest micro-organism on Earth is both ironic and tragic. Ironic because, despite of all available technology, financial system, and military power, the most effective weapon for this threat is based on social and political behavior - distancing, coordinated action and solidarity, and a long-term solution to the problem is based on values shift, citizenship, and courage to change how we operate as society. Tragic because the fight against the virus is actually a fight against ourselves. The pandemic is only a symptom of a development model that makes us the most destructive virus for the planet!

While the call for new development pathways is not new, the COVID-19 pandemic has rendered such need more explicit and urgent, as do the recognition that the root causes of the problem must be addressed. The saying 'we won't go back to normal, because normal was the problem' captures the essence of this call for transformation. The COVID-19 pandemic is only one symptom of major structural problems (SETTELE et al., 2020), entwined with other global crises such as climate change, nature deterioration, 
acute social inequalities, displacement and migration, consumerism, anti-democratic values, and financial market uncertainties.

Previous calls for change, to address global challenges such as climate change and poverty, have failed to trigger transformation due to their varying long-term and noticeable impacts across regions and populations. In contrast, the COVID-19 has spread worldwide concurrently and at similar pace. In addition, from the sick to the angry ones, the COVID-19 crisis has been embodied emotionally and economically in the lives of virtually every citizen in the world.

Whether this crisis will create cracks in the solid structure of global capitalism for a transformative process to emerge remains to be seen. It will depend on whether economic recovery stimulus will further promote perverse subsidies or will create incentives for transformation that account for the role of science in society, the role of the State in crisis management, the role of corporations in responsible and transparent innovations, and the role of citizens as politically actors and agents of change.

In Brazil, class, race and ethnicity have shaped a very unequal distribution of risks to this pandemic. However, the country holds an important weapon to fight this crisis in the long-run - the wealth of the Amazon and the creativity of its populations. Like many other forested systems in the world, the Amazon can be either the cradle of new pandemic if the 'old normal' of business as usual continues, or the stage for a new normal based on transformations to a more sustainable and equity-based society. Hopefully, the latter will prevail!

\section{Acknowledgements}

This study was financed by the AGENTS Project: Amazonian Governance to Enable Transformations to Sustainability, which is part of the Belmont Forum and NORFACE T2S Program and funded by FAPESP (Brazil), National Science Foundation (USA), NWO (The Netherlands), and Vetenskapsradet (Sweden).

\section{References}

APIB. Vidas Indígenas e o COVID-19. Articulação dos Povos Indígenas do Brasil, Brasília, 2020. Available at: http://apib.info/2020/05/14/1-vidas-indigenas-e-covid-19/. Accessed on: 20 may 2020.

AJZENMAN, N.; CAVALCANTI, T.; DA MATA, D. More than words: Leaders' speech and risky behavior during a pandemic. Social Science Electronic Publishing (SSRN), p. 1-36, 2020.

BHATIA, S. et al. Short-term forecasts of COVID-19 deaths in multiple countries. London: Imperial College London, 2020. Available at: https://mrc-ide.github.io/covid19-short-term-forecasts/index.html\#introduction. Accessed on 20 may 2020. 
BRASIL. Ministério da Saúde. COVID-19: Painel Coronavirus. Brasília, DF, 2020. Available at: https://covid.saude.gov.br/. Accessed on 22 May 2020.

BRENNEN, J. et al. Types, sources, and claims of COVID-19 Misinformation: Factsheet April. Oxford: University of Oxford \& Reuters Institute, 2020. Available at: http://www.primaonline. it/wp-content/uploads/2020/04/COVID-19_reuters.pdf. Accessed on: 21 may 2020.

DIAZ, S. et al. Investments' role in ecosystem degradation: Response. Science, v. 368, n. 6489, p. $377,2020$.

DI MARCO, M. et al. Sustainable development must account for pandemic risk. Proceedings of the National Academy of Sciences, v. 117, n. 8, p. 3888-3892, 2020.

ELOY, L.; BRONDIZIO, E.; PATEO, R. New perspectives on mobility, urbanisation, and resource management in Amazônia. Bulletin of Latin American Research (BLAR), v. 34, n.1, p.1-16, 2014.

FAUSTO, C. O sarampo do tempo de meu avô: memórias do etnocídio na pandemia. Nexo Jornal, São Paulo, 2020 Available at: https:/www.nexojornal.com.br/ensaio/debate/2020/O-sarampo-do-tempo-de-meu-av\%C3\%B4-mem\%C3\%B3rias-do-etnoc\%C3\%ADdio-na-pandemia. Accessed on 19 may 2020.

FERRANTE, L.; FEARNSIDE, P. Brazil's new president and 'ruralists' threaten Amazonia's environment, traditional peoples and the global climate. Environmental Conservation, v. 46, n. 4, p. 261-263, 2019.

HARVEY, D. Anti-Capitalist politics in the time of COVID-19. Jacobin Magazine, New York, 2020. Available at: https:/jacobinmag.com/2020/03/david-harvey-coronavirus-political-economy-disruptions. Accessed on 19 may 2020.

IPBES. Global assessment report of the Intergovernmental Science-Policy Platform on Biodiversity and Ecosystem Services. E.S. BRONDIZIO, J. SETTELE, S. DÍAZ, and H.T. NGO (eds). UN-IPBES, Bonn, 2019.

LE TOURNEAU, F; DROULERS, M. L'Amazonie Brésilienne et le Développement Durable. Paris, France: Belin, 2010.

MELLAN, T. et al. Estimating COVID-19 cases and reproduction number in Brazil. London: Imperial College London, 2020. Available at: https://www.imperial.ac.uk/mrc-global-infectious-disease-analysis/covid-19/report-21-brazil/. Accessed on 25 may 2020.

NAY, O. Can a virus undermine human rights? The Lancet, v. 5, n. 5, p. 238-239, 2020.

OXFAM. 5 shocking facts about extreme global inequality and how to even it up. Oxfam International, Geneva, 2020. Available at: https://www.oxfam.org/en/5-shocking-facts-about-extreme-global-inequality-and-how-even-it. Accessed on 20 May 2020.

PARRY, L. et al. Social vulnerability to climatic shocks is shaped by urban accessibility. Annals of the American Association of Geographers, v. 108, n. 1. p.125-143, 2018.

SETTELE, J. et al. COVID-19 stimulus measures must save lives, protect livelihoods, and safeguard nature to reduce the risk of future pandemics. Intergovernmental Science-Policy 
Platform on Biodiversity and Ecosystem Services (IPBES) Guest Article, Bonn, 2020. Available at: https://ipbes.net/covid19stimulus. Accessed on: 01 june 2020.

TOLEDO, P. et al. Development paradigms contributing to the transformation of the Brazilian Amazon: Do people matter? Current Opinion in Environmental Sustainability, v. 26-27, p.7783, 2017.

VANWAMBEKE, S.; LINARD, C.; GILBERT, M. Emerging challenges of infectious diseases as a feature of land systems. Current Opinion in Environmental Sustainability, v. 38, p.31-36, 2019.

WHO. WHO Coronavirus Disease (COVID-19): Dashboard. Geneva, 2020a. Available at: https://covid19.who.int/. Accessed on 20 May 2020.

WHO. Coronavirus disease 2019 (COVID-19): Situation Report - 85. Geneva, 2020b. 
Fabio de Castro

$\square$ f.decastro@uva.nl

ORCiD: https://orcid.org/0000-0001-5197-3863
Submitted on: 01/06/2020

Accepted on: 06/06/2020

2020;23:e0123

\section{Gabriela Russo Lopes}

$\square$ g.russolopes@uva.nl

ORCiD: https://orcid.org/0000-0002-0161-6339

\section{Eduardo Sonnewend Brondizio}

ఐebrondiz@indiana.edu

ORCiD: https://orcid.org/0000-0001-9376-8366

How to cite: CASTRO, F.; LOPES, R. L.; BRONDIZIO, E. S. The Brazilian Amazon in Times of COVID-19: from crisis to transformation?. Ambiente $\mathbb{\&}$ Sociedade. São Paulo, v. 23, p. 1-11, 2020. 


\section{A Amazônia Brasileira em Tempos de COVID-19: Da Crise à Transformação?}

São Paulo. Vol. 23, 2020

Ideias em debate

The COVID-19 epoch: Interdisciplinary research towards a new just and sustainable ethics

\author{
Fabio de Castro \\ Gabriela Russo Lopes \\ Eduardo Sonnewend Brondizio
}

Resumo: A crise do COVID-19 não é uma questão nova. As condições que levaram a isso estão tomando forma há décadas. Essa pandemia é um sintoma de problemas muito mais profundos, resultantes das estruturas contemporâneas de produção e consumo, desigualdades sociais, degradação da natureza e conectividade global. Pensar no mundo pós- pandemia é imaginar soluções que abordem as causas destes problemas. As comunidades locais e os grupos indígenas da Amazônia brasileira são uma fonte de inovações sociais, mais do que nunca necessárias, que se baseiam em visões alternativas da natureza e das relações sociais. Este ensaio tem como objetivo chamar a atenção para essas práticas como ponto de partida para repensar o presente e redefinir nosso futuro. Novos caminhos são necessários para superar o 'antigo normal' da região, marcado pela extração destrutiva de recursos e desigualdades sociais, e mudar para um 'novo normal', baseado em transformações para uma sociedade mais sustentável e equitativa.

Palavras-chave: COVID-19, Amazônia, Populações rurais, Populações Indígenas, Transformação sustentável

Como citar: CASTRO, F.; LOPES, R. L.; BRONDIZIO, E. S. A Amazônia Brasileira em Tempos de COVID-19: Da Crise à Transformação?. Ambiente \& Sociedade. São Paulo, v. 23, p. 1-11, 2020.

DOI: http://dx.doi.org/10.1590/1809-4422asoc20200123vu2020L3ID 


\section{La Amazonía Brasileña en Tiempos de COVID-19: De la Crisis hacia la Transformación?}

São Paulo. Vol. 23, 2020

Ideas en debate

The COVID-19 epoch: Interdisciplinary research towards a new just and sustainable ethics

\author{
Fabio de Castro
Gabriela Russo Lopes
Eduardo Sonnewend Brondizio \\ Fabio de Castro
Gabriela Russo Lopes
Eduardo Sonnewend Brondizio \\ Fabio de Castro
Gabriela Russo Lopes
Eduardo Sonnewend Brondizio
}

Resumen: La crisis de COVID-19 no es un problema nuevo. Las condiciones que han conducido a esto han venido tomando forma durante décadas. Esta pandemia es un síntoma de problemas mucho más profundos, originados de las estructuras contemporáneas de producción y consumo, las desigualdades sociales, la degradación de la naturaleza y la conectividad global. Pensar en un mundo posterior a la pandemia es imaginar soluciones que aborden las causas de estos problemas. Las comunidades locales y los grupos indígenas en la Amazonía brasileña son una fuente de innovaciones sociales, más que nunca necesarias, basadas en visiones alternativas de la naturaleza y las relaciones sociales. Este ensayo tiene como objetivo llamar la atención sobre estas prácticas como punto de partida para repensar el presente y redefinir nuestro futuro. Se necesitan nuevas vías para superar el 'viejo normal' de la región, marcada por la extracción destructiva de los recursos y las desigualdades sociales, y avanzar hacia un 'nuevo normal', basado en transformaciones hacia una sociedad más sostenible y equitativa.

Palabras clave: COVID-19, Amazonía, Poblaciones rurales, Grupos indígenas, Transformación sostenible

Como citar: CASTRO, F.; LOPES, R. L.; BRONDIZIO, E. S. La Amazonía Brasileña en Tiempos de COVID-19: De la Crisis hacia la Transformación?. Ambiente \& Sociedade. São Paulo, v. 23, p. 1-11, 2020.

DOI: http://dx.doi.org/10.1590/1809-4422asoc20200123vu2020L3ID 